\title{
Transitional friends? Young people's strategies to manage and maintain their friendships during a period of repositioning
}

\author{
Rachel Brooks
}

Published in the Journal of Youth Studies, December 2002

\section{Introduction}

Young people's relationships, both with close friends and others in their wider peer group, have been the focus of an extensive body of research within the disciplines of sociology, anthropology and psychology. Indeed, the peer-orientation of young people is widely assumed within much of this literature (Bukowski et al. 1996; Coleman and Hendry, 1999), as well as within more popular discourses about youth. Within the sociology of education, this focus has been particularly evident. A considerable number of studies have explored the impact of friendship groups on young people's experience of and performance within the education system (Aggleton, 1987; Hey, 1997; Mac an Ghaill, 1994; Winiarski-Jones, 1988), as well as the ways in which educational processes may themselves structure young people's relationships with their peers (Abraham, 1995; Ball, 1984; Eglin, 1984; Hargreaves, 1967). However, although the literature on educational choice has burgeoned over recent years (Gewirtz et al., 1995; Lauder and Hughes, 1999; Tomlinson, 1997), where it has focussed on informal relationships, it has generally concentrated on showing how friends and the wider peer group may influence young people's decisions about their education (Ball et al., 2000; Roker, 1993). Few studies have explored in any depth the ways in which engaging in the process of decision-making may itself affect young people's friendships. In an attempt to redress this gap, this paper suggests that it may be fruitful to explore the reciprocal influences that such processes exert on young people's friendships, and the ways in which these influences are embraced, resisted or pragmatically managed.

The paper draws on a study of young people's higher education (HE) choices to argue that the process of choosing particular HE institutions and courses made explicit certain social and status differences between friends: most noticeably differences in academic ability, likely higher education destination and, for some, outlook on life. In turn, these differences made the young people extremely reluctant to engage in conversations about higher education. Indeed, there were very few examples of any young person talking through their HE choices in any depth with a close friend. Recent theorising on the nature of friendships (Allan, 1996, 1998a, 1998b) would suggest that, as the young people became aware of such differences in social location, the equality of their friendships would come under increasing pressure and, in such circumstances, would be likely to change. However, there is compelling evidence from this research project that, although the portrayal of equality became difficult for many of the young people, their friendships did not change in this way. Indeed, the stability of many friendship groups was notable. This paper will argue that, instead of forging new friendships more congruent with 
their emerging social locations, the students used a variety of strategies to manage their existing friendships. After describing these strategies in some depth, the paper goes on to explore the likely reason why they were deployed and the implications this may have for our conceptualisation of friendship. It will consider whether similar strategies are practised in other friendships over the life-course, as an attempt to manage difference, or alternatively, whether they are symptomatic of the perceived 'transitional' nature of friendships in the years immediately preceding higher education.

\section{Methods}

This article draws upon a two-year case study of the experiences of fifteen young people between the ages of 16 and 18, and their friends, at 'Emily Davies College' (a pseudonym), a sixth-form college in the south of England. Each term, between September 1999 and September 2001, individual, in-depth interviews were held with the young people. These covered topics such as their experiences at college; plans for the future; thoughts and decisions about higher education; lives outside of college; and relationships with friends. In addition, various members of staff and careers advisers at the college were interviewed, and a number of HE-related events were observed. Emily Davies College is a large institution, with around 900 students in each year group and, typically, around 70 per cent of each cohort go on to higher education. The young people who took part in this research generally obtained GCSE and A Level results higher than the college average ${ }^{1}$, but did encompass a reasonably wide spectrum of attainment. In common with most of the other students at the college, they had attended local state secondary schools and came from broadly lower middle class families, with little experience of higher education (see Table 1).

\section{[Insert Table 1]}

\section{Emerging differences}

Over the course of the research, the young people talked at length about emerging differences between themselves and their friends. These included differences in: academic attainment, values, subject areas and the timing of HE decisions. While differences do not necessarily lead to difficulties in talking about HE choices, some of the differences did seem particularly problematic for the young people concerned because of the ways in which they threatened the perceived equality of their friendships. This was exacerbated in some cases by the hierarchical judgements made by the young people about some of these types of difference. Although few of these differences were created by the process of HE choice, or by the young people's experiences at sixth-form college, they do seem to have placed new tensions upon existing friendships. Indeed, the process of HE choice seems to have played an important role in making explicit previously latent differences. It was these emerging differences that made talking about HE with close friends difficult for many of the young people in this study.

\footnotetext{
${ }^{1}$ For students who took A Level exams in the summer of 2001, the mean A Level point score for the college as a whole was 16 (Department for Education and Skills, 2001). This compares to a mean of 20.4 for the young people who took part in this research.
} 
One of the most significant differences between friends and peers was that in academic attainment. Although several of the young people claimed that they had been aware of differences in academic attainment within their friendship group before arriving at Emily Davies College, it was only when embarking upon the process of $\mathrm{HE}$ choice that these differences gained such significance. Predicted grades determined, to a large extent, what courses and institutions could be considered by individual students and, thus, were seen by the young people as having serious implications for future careers. Becky articulated this well, when talking about her relationship with her best friend, Jane:

I mean we have always been different in that I've sort of been, you know, higher up in classes and grades and everything, but it's never really mattered. She has felt as though she had to try and live up to the same standards because she was my best friend and everything but, you know, it got to a certain point when she realised [there was no point] bothering. But now it's back to that point only it's much worse cos it's such a difference: her being here in college for a third year and me going to Oxford. (Interview 5)

Not only were the young people aware of the differences in academic attainment between themselves and their friends, but many anticipated that this would lead to them attending different types of university. Almost all employed some kind of ranking system to differentiate between institutions and most made some link between academic ability and type of HEI. Steve was explicit about how he perceived this relationship. After describing the differences in academic attainment amongst his friends, he went on to speculate that:

I would imagine that you're looking at, with Joe, the top band of universities, then you're looking at like myself and Ben, you're looking at maybe a bit lower, but still good standard universities. It's a bit like a cascade, a waterfall down towards...I think Marco, who's doing [a] GNVQ, I don't think he even wants to go to university...Y Yeah, I would imagine some of us will be going to different types of university entirely. (Interview 2)

Such differences in academic attainment, higher education institution and, for some of the young people, proposed degree subject and future career, were not seen as value-neutral; it was not simply a matter of making different choices. In almost all friendship groups, differences in these areas were positioned hierarchically, thus putting substantial pressure on the perceived equality of many friendships.

Allan (1998b) contends that: 'one of the principal features of friendships and other such non-kin sociable relationships is that those involved regard and treat one another as social equals' (p.76) and goes on to argue that:

Difference can be tolerated provided it does not undermine the sense that each party has of the other treating them as of equal social worth. Where such balance is missing, sustaining the relationship as friendship becomes problematic...friendships often lapse if one side's structural location alters sufficiently to make the routine portrayal of equality difficult (pp.76-77) 
Thus, change in friendship is seen as both routine and normal. Indeed, Allan argues that although the common understanding of friendship is based on ideas about solidarity, liking and trust, changes in the social position of one friend usually have considerable impact on the friendship itself: 'the relationships slowly become less active; gradually new friends who are compatible with the new status and developed life-style take their place' (p.97). By changing friendship networks in this way, Allan suggests that the individual is able to generate support for his or her new social identity. However, in contrast to these claims, there is compelling evidence from the research at Emily Davies College that, although the portrayal of equality certainly became difficult for many of the young people, their friendships did not change in this way. Indeed, the stability of many friendship groups over the two-year period was notable. Not only did friends continue to socialise together during the college day, but they also continued to see each other outside college. (Shopping together, meeting up at the pub, going clubbing and attending the same Church youth group were some of the activities mentioned by the young people).

\section{The stability of friendships}

Despite significant changes to their social location as the young people became aware of their likely higher education destinations, over the course of the research few young people reported any significant changes to their friendships. Moreover, a considerable number maintained close relationships with their friends from secondary school over their two years at Emily Davies College. Although in some cases groups had been enlarged with one or two new members, there was strong continuity in the friendships and many of the young people were able to trace back the history of their friendships to their early teenage years and to their secondary schools, in particular. In contrast to studies that have emphasised the 'ecological specificity' of young people's friendships - the ways in which the nature and basis of friendships can change across different contexts (Allen, 1981) - and the increasingly fluidity of such relationships in recent years (Schneider and Stevenson, 1999), most of the close friends of the young people in this study also attended Emily Davies College.

Not only was there continuity from school to college, but there was also strong continuity during college (in part supported by the college's policy of grouping students from the same feeder school together for tutor periods). Out of the fifteen young people, only two (Zoë and Rich) claimed to have moved into new friendship groups. All the other young people who took part in this research described the strong stability of their friendships. The following comments were typical:

Lucy: I met a few new friends through the courses that I did - but it was only a few. Generally, this group of people from...the school I went to stuck in a group and we stuck together, and they're the people I socialise with out of college - the same people I sat with when I had a break at college. (Interview 6)

Steve: $\quad$ We decided to stick to each to his own and that, rather than the hassle of mixing [with other students at college]....I'd never actually made a proper effort [to make new friends]. (Interview 6) 
Charlotte: I find it a bit difficult to make new friends because I've been in the same friendship group since I was really young....When we got there [college]...there was no one else there from our school so by default we had to like cling together. All of us stayed friends because we knew each other, we were doing a lot of the same stuff, so it was just easier. (Interview 6)

Despite clear indications that the young people at Emily Davies College were aware of different emerging social positions, there was no evidence that they had made any attempt to change their friends or to forge new friendships with young people with more similar and equal social locations. Instead, most of the young people in the sample employed a range of strategies to 'manage' the process of higher education choice and to maintain their friendships in the face of growing awareness of difference.

\section{Strategies to manage friendships}

\section{A typology of strategies}

In relation to this emerging awareness of difference, it is possible to identify five main strategies that the young people employed to manage their friendships during their two years at Emily Davies College: avoiding HE-related topics of conversation; refusing to engage in such conversations when initiated by others; concealing decisions and choices; misleading friends; and a pragmatic choice of confidantes. The first of these, avoidance, describes the way in which a number of young people took steps to avoid the topic of higher education with specific members of their friendship group. Becky's and Sunita's comments were typical of many:
Rachel: $\quad$ Do you think that puts strains on the friendship generally [differences in likely HE destinations]?
Becky: $\quad$ It's not because we've not discussed it really so it's not at all a problem. I'm sure it's going to be definitely between me and Jane when I go away because I'm so determined to move away to university....It's below the surface at the moment. We're trying to avoid it all. (Interview 4)

Sunita: $\quad$ To tell you the truth, I'd never heard of Lampeter and I was saying 'Where's that?' 'It's in Wales', 'OK, I'd never heard of it.' I was just thinking, she wants to go to a place that no one's ever heard. I won't say anything to her.....I didn't say anything to her. I thought it might be a bit rude.

Rachel: $\quad$ Why did you think it might be a bit rude?

Sunita: $\quad$ It might upset her a little bit: you know, 'You're applying to such a low university' or something. Cos she really wants to go. (Interview 5)

A second, and related, strategy can be identified as a young person's refusal to engage in an HE-related topic of conversation, when raised by others. In most cases this took the form of actively trying to change the subject. For example, Liz described how her girlfriend had refused to discuss higher education with her, 
primarily to avoid making explicit likely changes to their relationship, while Becky explained how she had refused to discuss universities with her friend Jane because of the unease she felt at the differences in their likely destinations in the coming year.

A further strategy described by the young people was to engage in a conversation about higher education but to conceal some specific aspect or detail of their own thoughts, decisions or choices. This was again illustrated well by Becky in her conversations with her wider friendship group. At the time of the first interview, most of her friends were aware that she was keen to go on to university. They did not, however, know about her ambition to study at Oxford or Cambridge:

Rachel: Is that something that you've consciously not told them?

Becky: $\quad$ Yes. It is actually. I know a lot of them feel a bit overshadowed by the grades that I get.....so I don't want to shove my achievements in their faces. So I don't say anything about it. (Interview 1)

This concealment continued until after the Oxford University open day, when she was required to explain her absence from college to her friends. Similarly, Steve acknowledged that, within his own friendship group, some people were likely to conceal the places and courses they were interested in, 'because they don't want to be seen as inferior' (Interview 2). This appeared to be the case for Mark, one of Steve's friends, who admitted that he was unlikely to talk about his interest in studying classical civilisation for fear of being teased - this was seen as a low status course amongst his friends.

Three students revealed that in their attempts to manage their friendships they had actively misled some of their friends about some aspect of their HE choices. For example, Jim articulated clearly the problems he envisaged if he was honest about his ambitions and, in particular, the differences that such talk would emphasise between him and his friends in his physics class (whom he perceived as more intelligent than him). Although he had applied for a physics foundation year at most of the institutions he had chosen, he explained that:

I don't tell a lot of people what I'm doing or if I do I say 'management'. I don't say the physics cos, I don't know...it's not...cos some people will say 'Management and physics? You're not good enough to do physics.'...I just feel a bit insecure about it I guess cos I feel a bit...I'd feel very put down if they said I wasn't good enough. But that's what I want to do. (Interview 5)

Although the young people at Emily Davies College rarely engaged their close friends in discussions about higher education, many had talked about their choices with at least some of their peers (although, in most cases, this was not at any great length), thus suggesting that a further strategy was employed to maintain friendships: the pragmatic choice of confidantes - reflecting, in many ways, the 'contingency friends' that Griffiths (1995) describes in her study of young women's friendships. As I suggested earlier, the process of HE choice highlighted, often for the first time, a number of differences between friends (such as: differences in academic attainment; likely HE destination and career; and, in some cases, values), and imbued them with considerable significance. The grounds upon which the young 
people selected their confidantes reflected these differences very closely. For example, several young people spoke to those whom they perceived as having a similar level of commitment to higher education as them. For Sunita, it was important to talk to someone who was equally keen to apply:

$\begin{array}{ll}\text { Sunita: } & \text { I can speak a bit more openly with Isobel, but not with } \\ & \text { everybody else. } \\ \text { Rachel: } & \text { Why's that? } \\ \text { Sunita: } & \text { Because we're both like on the same road. We're both doing } \\ & \text { geography, we both want to go to university desperately. The } \\ & \text { others, I don't think they are interested, really. Us two, we } \\ \text { think the same because we both want to go, but my other } \\ \text { friends, they are like, they don't have that feel. (Interview 3) }\end{array}$

Others, however, were more concerned to talk to students who, like them, were having doubts about the future and who were more ambivalent about higher education.

Similarity was not the only basis for selecting confidantes, however. Three of the young people, at various points over the two-year period, actively took steps to avoid conversations with those they perceived to be similar to them. Jim's case serves as a good illustration of this. Although he shared with many of his friends in his physics class a strong interest in physics and a desire to go on to study the subject at university, he was careful to avoid discussing higher education with them. Instead, he turned to other friends who were studying arts-based subjects. He explained that this was because:

...they're all doing art and photography and stupid things and it's easier to talk to them cos they don't judge your intelligence. They just presume I'm intelligent cos I'm doing physics and they think 'Oh yeah, you're doing that [physics at university] cos it sounds good for you.' (Interview 4)

\section{The purpose of the strategies}

The strategies adopted by the young people had the overall aim of maintaining their friendships during a period in which the equality of the friendship tie was being threatened by emerging differences and a growing awareness of different social locations both now and in the future. Strategies were used to mask, or at least to deflect attention away from, the various types of emerging difference such as: probable HE destination, level of academic attainment, view of university life, and the implied status differences associated with these specific areas; and seem to have served two main purposes.

\section{Protecting themselves}

The various strategies differed in terms of whom they were aimed at - whether they were intended to mask the young person's own position or that of one or more of their friends. Several of the young people were concerned to protect themselves; to ensure that they were not perceived as deviating too significantly from group norms. This was a particularly common strategy when the young person saw himself or 
herself as different from an otherwise fairly homogenous group. Becky, Sunita and Jim typified this response. At several points throughout the research Becky, who was keen to go to Oxford University, talked about how she felt different from her close friends in terms of higher education ambitions and also probable destinations and how this had motivated her to avoid such conversations or to actively mislead her friends. Similarly, Sunita felt that the importance she placed on institutional status and the time she had devoted to finding out about universities and colleges differentiated her from her close friends. Her strategies of avoidance were driven by the thought that, if she talked about her decisions, her friends would probably not share her values and thus find her boring. As discussed above, Jim misled his friends about his own HE intentions, claiming that he had applied to read management rather than physics. This was prompted by a lack of confidence in his own ability and a belief that he was not as intelligent as his friends in his physics class. These young people were seeking to maintain their friendships by concealing what they perceived as the growing distance between themselves and the other members of their friendship groups.

\section{Protecting their friends}

Secondly, many of the strategies employed by the young people were motivated by a desire to protect their friends and, in particular, individuals whom they (and, in most cases, others within the friendship group) perceived as deviating from group norms or whom they saw as occupying lower positions than them on the emerging hierarchies of academic ability and institutional status. This kind of reasoning was employed by many of the young people at various points throughout the two-year period and is illustrated by Lucy's concern about her friend, Megan:

Lucy: $\quad$ One of my friends got a bad result in her exams so we don't really like to say - cos it's three Bs to do this public relations course - and she got like really bad results so now she just wants to go to [an institute of higher education] cos she thinks that's the only place she can go.... so in that aspect, we can't say 'Oh God, I've got to get three Bs' - when she got really bad results, we can't really say [that] in front of her.

Rachel: $\quad$ So, is that something you've tried not to bring up? Lucy: $\quad$ Yeah. (Interview 3)

This suggests that many of the young people took considerable steps to maintain an illusion of equality in their friendships. In her study of adolescent girls, Lees (1993) claims that 'boasting for men is about enhancing status, but for women it violates girls' egalitarian ethic, which emphasizes connection and similarity' and goes on to suggest that 'girls fear rejection if they appear too successful' (p.83). In contrast, as the evidence above demonstrates, at Emily Davies College both the young men and the young women seemed to possess an 'egalitarian ethic', which informed the practice of their friendships; the importance of at least a perception of equality within friendships, emphasised in both the sociological and psychological literature (Allan, 1998a; Douvan and Adelson, 1966; Bukowski et al., 1996), seemed as important to the young men as to their female counterparts. 


\section{Explaining the strategies}

The strategies that have been outlined in this paper were evident throughout the twoyear period of data collection at Emily Davies College. Almost all of the young people described ways in which they had tried to manage their existing friendships. The compelling evidence that they provided, of the ways in which increasingly unequal friendships were maintained, prompts two closely related questions. First, why did they employ these strategies? And second, why did they not change their friends?

\section{The significance of educational differences}

I would suggest that there are three possible responses to these questions. The first is to argue that the differences between the young people in terms of academic attainment and likely higher education destination were not particularly significant. They continued to share other, more important, aspects of their lives and these ensured that they also continued to perceive their social locations as similar. Miles (2000), for example, argues that it is youth lifestyles and, in particular, consumer lifestyles that give meaning to young people's lives and play a central part in the construction of their identities. Thus, despite significant differences in attainment, a shared 'consumer lifestyle' amongst friends could ensure the continuation of a perceived similarity in social location. Dwyer and Wyn (2001) also emphasise the multi-dimensional nature of many young people's lives. Indeed, they claim that one of the effects of prolonged entry into career paths over recent decades has been to allow young people more time to assess their priorities concerning their adult lives, serving 'to reinforce the belief that the other areas of life are of at least equal importance' [to education and career] (p.188). Alternatively, Blackman (1995) found that, among the high achieving 'boffin' girls in his study, there were no divisions based on their educational aims or academic status. Instead, the basis of division within the friendship group was level of knowledge about, and experience of, heterosexual relations. Within the terms of these various analyses, academic standing relative to friends and awareness of different educational futures may seem relatively unimportant.

Although, theoretically, these are plausible arguments, they are not consistent with the data from this research. The language the Emily Davies students used to talk about the differences between themselves and their friends, and the significance they attached to these differences, suggests that educational destinations were extremely important to them. Indeed, the effort required to pursue the strategies outlined in this paper lends weight to this hypothesis. Furthermore, higher education decisions were not viewed solely as a choice about education per se; they were inextricably bound up with other decisions about career and lifestyle and, as such, were imbued with considerable significance. In many cases, differing views about higher education reflected differing attitudes to, for example, the future, the importance of moving away from home and, in some cases, the nature of friendship itself. Moreover, there is evidence from other sources that, at the turn of the twenty-first century, young people are continuing to see education as central to their life chances and future social location. For example, Roberts (1997) argues that the things that remain most important to most young people are their education, families and future job prospects (rather than their leisure pursuits), while Savage (2000) suggests that over the last 
few decades, as class effects have become increasingly mediated through educational processes, doing well educationally has become progressively more important for all young people.

It seems likely that the importance of educational difference in the young people's lives was also heightened by other broad social and cultural values, prevalent both inside and outside the college and, in particular, the importance attached to competition. In her study of US schools, Lesko (2001) argues that a competitive ethos pervades educational institutions and is partially derived from more general social values: 'these bureaucratic arrangements are contextualised within and influenced by a nationalistic exhortation to compete harder and better....the broader US society and our schools boastfully advertise these traits and their benefits' (p.186) - and similar competitive cultures have been identified within British schools and colleges (Gillborn and Youdell, 2000). Thus, while Allen's (1981) and Blackman's (1995) assertions that academic achievement often gives young people access to high status and various privileges within a school community are not necessarily supported by the data discussed in this paper, it seems highly likely that educational differences were of considerable importance to the Emily Davies students because of the way in which they believed them to be intimately related to status and social differences recognised by and of significance within the outside world.

\section{The uniqueness of young people's friendships?}

A second possible explanation for the use of the strategies described in this paper would emphasise the similarities between the young people's friendships and others that are made and maintained throughout the life-course. This would argue that the differences and difficulties apparent in the young people's friendships are inherent in many other friendships and that, instead of being predicated upon a strong mutual perception of similarity, in practice, friendship involves a continual negotiation of difference.

This explanation would suggest strong parallels between the friendships of children and adolescents and those of older people. Traditionally, many sociologists, psychologists and anthropologists have distinguished clearly between the types of friendship forged in childhood and adolescence and those made later in life (Berndt, 1999; Duck, 1983; Hendry et al., 1993; Hunter, 1985; Reed-Danahay, 1999). One of the clearest statements of this is provided by Douvan and Adelson (1966) who claim that: 'The peer relations of adolescence are part of the preparation for adult love and friendship: by loving and being loved, by making friends and being befriended, the child learns something of the vicissitudes of affection.... because it carries so much of the burden of adolescent youth, friendship acquires at this time a persistence and intensity it has never had before nor (in many cases) will ever have again' (p.174). This is contrasted with adult friendship, which they maintain is 'no more than a mutual flight from boredom - a pact against isolation, with an amendment against intimacy' (p.178).

However, as Allen (1981) notes, there is no general agreement about whether children and young people's friendships are different from those formed at other points in the life-course. For example, research that has focused specifically on the 
construction of difference has highlighted significant similarities across age groups. Children's and adolescents' friends are typically of the same sex (Banks et al., 1992; Walker, 1988), social class (Blackman, 1992; Hey, 1997; Mac an Ghaill, 1994; Rezende, 1999) and ethnic background (Fuller, 1984; Hewitt, 1986; Walker, 1988), leading Jamieson (1998) to conclude that: 'it seems that children quickly learn to reproduce wider social divisions and inequalities' (p.94) - a process which continues into later life. Such claims resonate with wider debates about the extent to which 'youth' constitutes a distinct and easily delineated period in one's life. Wallace and Kovatcheva (1998) and Lesko (2001), for example, argue against an essentialist understanding of youth, pointing out that the precise age that is associated with youth differs between societies and that factors which appear to be psychological or biological universals often turn out to be socially relative. Roberts (1997) and Dwyer and Wyn (2001) pursue this argument further, maintaining that a general destandardization of the life course (resulting from changes to both the labour market and the practice of relationships) has led to greater variety within all age groups, thus making it 'hazardous to generalize about the circumstances and behaviour of people at any given age...there is no longer a normal situation for a person aged 18, 21 or 25' (Roberts, 1997, p.3). This suggests that it may be unwise to assume the uniqueness of young people's friendships.

Other empirical evidence of the differences and difficulties inherent in young people's friendships would lend weight to this position. For example, Hey (1997) argues that for the girls (aged between 11 and 18) involved in her research, friendship groups helped them define themselves against others, rather than affirm their similarity or increase their identification with each other. Indeed, many of the friendships she describes were ridden with competition and an awareness of withingroup difference. There is also a growing body of evidence documenting the complexity of the friendships of older people. Historical studies of informal relationships have shown how, in the past, many friendships were built on status inequality, primarily to avoid jealousy and rivalry (Silver, 1989), while Zeldin (1995) argues that it has been common for friendships to be 'confused with pride and clashed with competitiveness' (p.322). Furthermore, Pahl (2000) suggests that within contemporary society:

As friends become closer and more salient for people's identities and serve as the focus for resolving some of their internal problems, so they, too can become enmeshed in a complex emotional maelstrom... They may bring out deep and unresolved feelings of guilt. (p.129-30)

He argues that the importance attached to friendship at the turn of the twenty-first century increases the likelihood of 'buried emotions' such as jealousy, anger and competitiveness being experienced between friends. Jamieson (1998) conceptualises friendship in a different way, largely in opposition to the idea of the 'pure relationship' put forward by Pahl $(1998,2000)$ and Giddens (1992), but also points to the tensions and difficulties inherent in contemporary adult friendships. She contends that few friendships fulfil the widely-held ideals of friendship (such as being honest, trusting and open within the relationship), asserting instead that 'people actually settle for more modest forms' (p.165). 
However, stronger empirical evidence is required in order to claim that the strategies employed by the Emily Davies students, in the face of increasing inequalities, are reflected in attempts to maintain friendships at other points in life. Although there are a small number of examples of adults attempting to negotiate hierarchies and inequalities in their friendships (Zorn, 1995) and deceiving their friends (Miller et al., 1986), further research is needed to explore whether the differences, difficulties and strategies for maintaining friendships outlined in this paper are replicated widely within adult friendships.

\section{Transitional friendships?}

A third, and final, possible explanation for the effort exerted by many of the young people in maintaining their friendships, is that they viewed their friendships as transitional and subject to inevitable change on entry to higher education. Although managing existing friendships required some effort, it was ultimately less timeconsuming, and possibly less stressful, than forging new friendships during the two years of sixth-form college. This thesis is more congruent with the young people's narratives than either of the theses outlined previously: many talked at length, and in several interviews, about how they expected their friendships to change quite considerably when they began university.

Lucy: $\quad$...we've all been together since we were 11, since school... and we know that we're.....cos we do this thing at Christmas, we get together, and everyone's saying 'This is going to be our last Christmas altogether, cos everyone's moving to different places', cos I know a couple of my friends are going to Loughborough and another really wants to go to Nottingham to do law and one of my friends is staying here and then you're got people who are working and me moving away. It's weird cos we've always... we came to college from school together.... (Interview 4)

Simon: I mean university is probably the time you want to break away and meet new friends and stuff. I mean, still have them, but go off on your own a bit. (Interview 5)

Clare: I want to go away and start again.

Rachel: $\quad$ Is that quite important to you - making new friends?

Clare: $\quad$ Yeah. I want to get some new experiences and things. (Interview 5)

In their accounts of the new friendships they anticipated making at university, the young people echoed Pahl's (2000) belief that friendships made in higher education are characterised by a particularly strong type of bonding. He argues that:

...the expansion of higher education, especially among women, has greatly increased the opportunity for making friends. A growing proportion of young people in their early twenties who are in higher or further education also have the time and opportunity to make friends to match their emerging identities. (p.171) 
In his view, friendships are strengthened by the shared experience of living away from home for the first time and facing problems together. Many of the young people involved in this research seemed to hold similar views about their future friendships. It is arguable whether the quality of university friendships is as clearly distinguished from friendships made at other points of the life-course as Pahl suggests - particularly when an increasing numbers of students are choosing to live at home (UCAS, 2000). Nevertheless, the ideal of such relationships was widely subscribed to by the Emily Davies students and, as such, may have provided strong motivation to postpone changes to friendships while at sixth-form college.

Implicit in several of the young people's accounts was an awareness that their friends may not share their own views of friendship nor their views of the increasing inequality of their relationship. This may have made forging new friendships while at college more problematic, and have provided further motivation to postpone changes until at university - when geographical distance would make such changes less difficult. The perceived transitory nature of many of the friendships is again suggested in these accounts:

Jim: $\quad$ She [girlfriend] was going to come to Sussex but....it may sound a bit harsh but I said to her, 'I don't want to go to the same university as you cos I want my independence.' It's not as though I split up with her. It's just that I wanted to be thrown in at the deep end, so to speak. If I was like stuck with people I already knew I wouldn't be so expressive and I wouldn't make friends which is what I believe is the whole point of university, apart from getting your degree....so I didn't really discuss it much with her cos she really got upset. (Interview 5)

Zoë: $\quad$...I don't want to talk too much cos a lot us are going to Southampton or have put that as our first choice and I don't know, I kind of want to move on a bit, find and meet other people, kind of thing. I don't want to sort of say 'Yeah, we're all applying to Southampton' so that other people think 'I'll apply to Southampton as well'.

Rachel: $\quad$ So why don't you want to talk about it with other people who are going to Southampton?

Zoë: $\quad$ Well, they'll talk about 'Oh we can get a flat together' and I'm like 'No, no!' (Interview 5)

Becky: $\quad$ Some of the others...they have done things because they thought they'd have the safety net of having old friends with them or whatever, so....

Rachel: $\quad$ But that kind of thing isn't important to you?

Becky: It's not really. Cos you're not going to have them for the rest of your life, so you've got to get used to it at some point. (Interview 5)

This interpretation of the young people's friendships as 'transitional' articulates with part of Lesko's (2001) argument about the way in which 'time' has been understood 
in adolescence. She suggests that since the beginning of the twentieth century, the transitory nature of adolescence has been emphasised. Youth have been defined as 'always "becoming", waiting for the future to arrive' (p.131), a definition which has provoked 'endless watching, monitoring and evaluating' (p.111) on the part of adults, and a passivity on the part of young people as they are told that only the future matters, and that it is the end of the adolescent story that is key. Similar themes resonate within the accounts of the young people at Emily Davies College that have been discussed above; many contrasted their present friendships with the more fulfilling relationships they hoped to form in the future (and at university, in particular) and, as a consequence, were prepared to put up with apparently unsatisfactory relationships in the short term. However, it would seem wrong to equate this with passivity: while the young people were certainly putting off making changes to their friends, they were also engaged in a very active process of managing their friendships.

\section{(Re)conceptualising young people's friendships}

As some of the preceding discussion may have suggested, many of the ways in which young people's relationships have been conceptualised seem to be predicated on a largely functionalist understanding of friendship. As Morris and Fuller (1999) note: 'Adolescence is commonly conceptualised as a time when young people move away from the confines of the family and look to the peer group for support from others going through similar experiences' (p.532). Establishing one's own identity, distinct from the family, is seen as a key process of 'youth' (Krappman, 1996) and one which is facilitated by friends and peers: 'Like seeks like, and while this is generally true at all ages, it is, we feel, more apt to be so during the adolescent period....the need is to define personal identity; to accomplish this, the youngster needs the reassurance and mirroring offered by others of the same disposition' (Douvan and Adelson, 1966, p.183). Indeed, Lesko (2001) argues that an orientation towards peers is one of the central ways in which adolescence has been characterized since the early twentieth century. However, the evidence presented in this paper does not accord with these functionalist interpretations of young people's friendships; the deep ambivalences that underlay many of the friendships suggests that the unconditional 'reassurance' and 'mirroring' assumed by Douvan and Adelson was extremely unlikely.

Similar functionalist assumptions also underpin recent theorising of the 'pure relationship' (Beck and Beck-Gernsheim, 1995; Giddens, 1992; Pahl, 1998). While these theorists differ from those discussed above by emphasising the greater degree of choice an individual has with regards to whom he or she forms close friendships with, they largely concur in their views of the function of such relationships. For example, Pahl (1998) argues that:

In a seemingly more risky world, where neither employment nor family relationships may be able to provide an enduring sense of security, certain kinds of friendships may provide a vital source of happiness and affirmation of personal identity. (p.103)

When asked to describe their friendships in abstract terms, the language the young people in this study used was indeed similar to that drawn upon by Pahl and others to 
characterise the 'pure relationship', emphasising complete openness and mutual disclosure. Nevertheless, as this paper has demonstrated, there was a strong disjuncture between this language and the actual ways in which friendships were conducted and friends were 'managed' - at least in terms of conversations and decisions about HE. In practice, active and mutual trust, self-disclosure through talk, and opening oneself up to the other were all noticeably absent from the friendships of the young people. Indeed, this paper has suggested that Pahl's contention that: 'between friends we talk about our futures, our ideals and larger-than-life meanings...there is an idealism in strong friendship because it is detached from the fixtures of role, status and custom' (p.113) fits uneasily with the experiences of the Emily Davies students.

The relatively small number of young people involved in this study does not provide a broad enough base upon which to develop a new theoretical understanding of friendship. However, I believe this paper has shown that a functionalist conceptualisation of friendship does not adequately explain the ways in which the young people in this study managed their friendships over their two years at sixthform college. Instead, I would support Lesko's (2001) assertion that the peerorientation of young people has been over-stated in much of the literature on adolescent relationships. Far from using their friends as 'mirrors' to establish their own identity, or building fully open, honest and emotional 'pure relationships', the young people managed their friendships in highly pragmatic ways, aware of the tensions, difficulties and points of difference inherent in their social bonds.

\section{Conclusion}

This paper has shown that the majority of the young people who took part in this study maintained very stable friendships during their two years at Emily Davies College. In part, this was supported by the way in which the college chose to organise the students: young people from the same feeder secondary school were often allocated to the same tutor group and in this way were able to consolidate existing friendships during 'college time'. Nevertheless, it is clear that the young people themselves also played an important role in ensuring this stability. Previous studies of friendship have emphasised the fluidity of such relationships, particularly when the social location of individuals changes and friends no longer perceive themselves to be socially equal. However, evidence from this study suggests that sociologists have tended to overstate the degree of change that follows from an awareness of growing difference and inequality. In this case, at least, friends employed a range of strategies to manage and maintain relationships that they recognised to be increasingly unequal. These included: avoiding HE-related topics of conversation; refusing to engage in such conversations when initiated by others; concealing decisions and choices; and misleading friends. The young people also chose confidantes on a purely pragmatic basis, often bypassing close friends in favour of another friend or peer whom they perceived to be more similar in some key aspect of the decision-making process. This allowed them to discuss specific aspects of their higher education decisions, while avoiding the difficulties that they feared such conversations would prompt if they had been held with close friends. 
In seeking to explain the reason why the Emily Davies students employed such strategies, and were so concerned to maintain their existing friendships, I have proposed three possible theses. First, it could be argued that the differences and inequalities which were highlighted by the process of higher education choice were not of great importance to the young people and, for this reason, presented little threat to the equality of the friendship tie. However, this is not supported by the young people's accounts: many spoke clearly about mutual perceptions of inequality and the strains this had placed on their friendships. Their higher education choices were, patently, of great importance to them, not least because for many of the young people they were linked to emerging values, ideas about careers and lifestyle decisions. A second, and more plausible explanation rests on the assumption that the differences and difficulties that the young people described when talking about their friendships, and the strategies they employed to manage these relationships, are not unique to them. Indeed, there is some, albeit limited, evidence that friendships at other points in the life-course are wrought with similar tensions. Nevertheless, the empirical evidence remains ambivalent - and theorising on the nature of friendship continues to emphasise the importance of perceived similarity, or 'status homophily'.

Finally, I have suggested that the young people at Emily Davies College may have viewed their friendships as 'transitional' and have anticipated that change was inevitable on entry to higher education. This may have provided strong motivation to postpone any changes until they arrived at university or college - when making such changes would, anyway, be much less problematic due to the likely geographical separation of friends. This thesis is strongly supported by the data: almost all the young people envisaged substantial changes to their friendship networks during their time in higher education and subscribed to a very particular ideal of the university lifestyle. As such, I would argue that it represents the most plausible of the three theses. Nevertheless, further research is clearly needed to explore whether the kind of strategies so prevalent amongst the Emily Davies students are practised by others, and at other points in the life-course.

\section{Acknowledgements}

I would like to thank the young people at Emily Davies College who gave up so much of their time to talk to me, and the ESRC for funding the research upon which this paper is based (award number: R00429944049). I am also very grateful to Sue Heath and an anonymous referee for their helpful comments.

\section{References}

ABRAHAM, J. (1995) Divide and School: gender and class dynamics in comprehensive education (London, Falmer Press).

AGGLETON, P. (1987) Rebels without a cause?: middle class youth and the transition from school to work (Lewes, Falmer Press).

ALLAN, G. (1996) Kinship and Friendship in Modern Britain (Oxford, Oxford University Press). 
ALLAN, G. (1998a) Friendship, sociology and social structure, Journal of Social and Personal Relationships, 15, 5, pp.685-702.

ALLAN, G. (1998b) Friendship in the private sphere in: ADAMS, R. and ALLAN, G. (Eds) Placing Friendship in Context (Cambridge, Cambridge University Press).

ALLEN, V. (1981) Self, social group, and social structure: surmises about the study of children's friendships in: ASHER, S.R. and GOTTMAN, J.M. (Eds) The Development of Children's Friendships (Cambridge, Cambridge University Press).

BALL, S. (1984) Banding, identity and experience in HAMMERSLEY, M. and WOODS, P. (Eds) Life in School. The Sociology of Pupil Culture (Milton Keynes, Open University Press).

BALL, S., MAGUIRE, M. and MACRAE, S. (2000) Choice, Pathways and transitions Post-16. New Youth, New Economies in the Global City (London, RoutledgeFalmer).

BANKS, M., BATES, I., BREAKWELL, G., BYNNER, J., EMLER, N., JAMIESON, L. and ROBERTS, K. (1992) Careers and Identities (Milton Keynes, Open University Press).

BECK, U. and BECK-GERNSHEIM, E. (1995) The Normal Chaos of Love (Cambridge, Polity Press).

BERNDT, T. J. (1999) Friendships in Adolescence in: WOODHEAD, M., FAULKNER, D. and LITTLETON, K. (Eds) Making Sense of Social Development (London, Routledge).

BLACKMAN, S. (1992) Pro-School Pupils: a case study of 'boffin' girls and boys inside and outside the school, Youth and Policy, 38, pp.1-9.

BLACKMAN, S. (1995) Youth: Positions and Oppositions. Style, sexuality and schooling (Aldershot, Avebury).

BUKOWSKI, W., NEWCOMB, A. and HARTUP, W. (Eds) (1996) The Company They Keep. Friendship in Childhood and Adolescence (Cambridge, Cambridge University Press).

COLEMAN, J.C. and HENDRY, L.B. (1999) The Nature of Adolescence $3^{\text {rd }}$ edition. (London, Routledge).

DEPARTMENT FOR EDUCATION AND SKILLS (2001) School and College (Post 16) Performance Tables

$<$ http://www.dfes.gov.uk/performancetables/16to18_01.shtml >

DOUVAN, E. and ADELSON, J. (1966) The Adolescent Experience (New York, John Wiley and Sons Inc.). 
DUCK, S. (1983) Friends for Life: the psychology of close friendships (Brighton, Harvester Press).

DWYER, P. and WYN, J. (2001) Youth, Education and Risk. Facing the Future (London, RoutledgeFalmer).

EGLIN, G. (1984) Public schools and choice at 18+ in WALFORD, G. (Ed) British Public Schools: policy and practice (Lewes, Falmer Press).

FULLER, M. (1984) Black girls in a London comprehensive school in: DEEM, R. (Ed) Schooling for Women's Work (London, Routledge and Kegan Paul).

GEWIRTZ, S., BALL, S. and BOWE, R. (1995) Markets, Choice and Equity in Education (Buckingham, Open University Press).

GIDDENS, A. (1992) The Transformation of Intimacy. Sexuality, Love and Eroticism in Modern Societies (Cambridge, Polity Press).

GILlBORN, D. and YOUDELL, D. (2000) Rationing Education. Policy, Practice, Reform and Equity (Buckingham, Open University Press).

GRIFFITHS, V. (1995) Adolescent Girls and Their Friends. A feminist ethnography (Aldershot, Avebury).

HARGREAVES, D.H. (1967) Social Relations in a Secondary School (London, Routledge and Kegan Paul).

HENDRY, L., SHUCKSMITH, J., LOVE, J and GLENDINNING, A. (1993) Young People's Leisure and Lifestyles (Adolescence and Society Series) (London, Routledge).

HEWITT, R. (1986) White Talk, Black Talk. Inter-Racial Friendships and Communication amongst Adolescents (Cambridge, Cambridge University Press).

HEY, V. (1997) The Company She Keeps. An Ethnography of Girls' Friendship (Buckingham, Open University Press).

HUNTER, F.T. (1985) Adolescents' perception of discussions with parents and friends, Developmental Psychology, 21, 3, pp.433-440.

JAMIESON, L. (1998) Intimacy. Personal Relationships in Modern Societies (Cambridge, Polity Press).

KRAPPMAN, L. (1996) Amicitia, drujba, shin-yu, philia, Freundschaft, friendship: on the cultural diversity of a human relationship in: BUKOWSKI, W., NEWCOMB, A. and HARTUP, W. (Eds) The Company They Keep. Friendship in Childhood and Adolescence (Cambridge, Cambridge University Press).

LAUDER, H. and HUGHES, D. (1999) Trading in Futures. Why Markets in Education Don't Work (Buckingham, Open University Press). 
LEES, S. (1993) Sugar and Spice. Sexuality and Adolescent Girls (London, Penguin).

LESKO, N. (2001) Act Your Age! A Cultural Construction of Adolescence (New York, Routledge Falmer).

MAC AN GHAILL, M. (1994) The Making of Men: masculinities, sexuality and schooling (Buckingham, Open University Press).

MILES, S. (2000) Youth Lifestyles in a Changing World (Buckingham, Open University Press).

MILLER, G.R., MONGEAU, P.A. and SLEIGHT, C. (1986) Fudging with Friends and Lying to Lovers: deceptive communication in personal relationships, Journal of Social and Personal Relationships, 3, pp.495-512.

MORRIS, K. and FULLER, M. (1999) Heterosexual Relationships of Young Women in a Rural Environment, British Journal of Sociology of Education, 20, 4, pp.531-543.

PAHL, R. (1998) Friendship: the social glue? in: FRANKLIN, J. (Ed) The Politics of Risk Society (Cambridge, Polity Press).

PAHL, R. (2000) On Friendship (Cambridge, Polity Press).

REED-DANHAY, D. (1999) Friendship, Kinship and the Life Course in Rural Auvergne in: BELL, S. and COLEMAN, S (Eds) The Anthropology of Friendship (Oxford, Berg).

REZENDE, C.B. (1999) Building Affinity through Friendship in: BELL, S. and COLEMAN, S (Eds) The Anthropology of Friendship (Oxford, Berg).

ROBERTS, K. (1997) Same activities, different meanings: British youth cultures in the 1990s, Leisure Studies, 16, pp.1-15.

ROKER, D. (1993) Gaining the Edge. Girls at a Private School in BATES, I. and RISEBOROUGH, G. (Eds) Youth and Inequality (Buckingham, Open University Press).

SAVAGE, M. (2000) Class Analysis and Social Transformation (Buckingham, Open University Press).

SCHNEIDER, B. and STEVENSON, D. (1999) The Ambitious Generation. America's Teenagers - Motivated but Directionless (New Haven and London, Yale University Press).

SILVER, A. (1989) Friendship and Trust as Moral Ideals: an Historical Approach, European Journal of Sociology, 30, pp.274-97. 
TOMLINSON, S. (1997) Diversity, choice and ethnicity: the effects of educational markets on minorities, Oxford Review of Education, 23, 1, pp.63-76.

UCAS (2000) More students apply to stay at home, Press release issued on 21/7/00 $<$ http://www.ucas.ac.uk/new/press/apps0700.html>

WALKER, J.C. (1988) Louts and Legends. Male Youth Culture in an Inner City School (London, Allen and Unwin).

WALLACE, C. and KOVATCHEVA, S. (1998) Youth in Society. The Construction and Deconstruction of Youth in East and West Europe (Basingstoke, Macmillan).

WINIARSKI-JONES, T. (1988) Adolescent Peer Groups: their formation and effects on attitudes towards education and academic performance, Research in Education, 40, pp.50-58.

ZELDIN, T. (1995) An Intimate History of Humanity (London, Minerva).

ZORN, T. E. (1995) Bosses and Buddies: constructing and performing simultaneously hierarchical and close friendship relationships in: WOOD, J.T and DUCK, S. (Eds) Understanding Relationship Processes 6: Understudied Relationships. Off the Beaten Track (Thousand Oaks, CA, Sage). 